\title{
Design Thinking David Kelley \& Tim Brown: Otak Dibalik Penciptaan Aplikasi Gojek
}

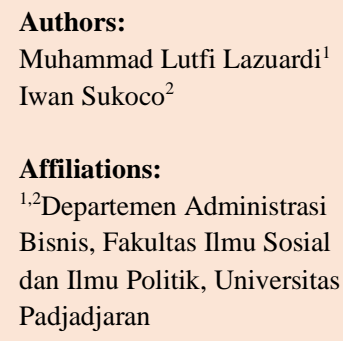

Corresponding Author:

Muhammad Lutfi Lazuardi

Emails:

1muhammad18109@mail.unpa

d.ac.id.

2iwan.sukoco@unpad.ac.id

\section{Article History:}

Received: February 21, 2019

Revised : May 5, 2019

Accepted: June 4, 2019

How to cite this article: Lazuardi, M. L., \& Sukoco, I. (2019). Design Thinking David Kelley \& Tim Brown: Otak Dibalik Penciptaan Aplikasi Gojek. Organum: Jurnal Saintifik Manajemen dan Akuntansi, 2(1), 1-11. doi: https://doi.org/10.35138/organu $\underline{\text { m.v2i1.51 }}$

\section{Journal Homepage:} ejournal.winayamukti.ac.id/ind ex.php/Organum

\section{Copyright:}

(C) 2019. Published by Organum: Jurnal Saintifik Manajemen dan Akuntansi. Faculty of Economics and Business. Winaya Mukti University.

Abstract. This study aims to describe each stage of design thinking at PT Karya Anak Bangsa (Gojek) to create appropriate and practical solutions to problems that arise in the community. The methodology used for this research was a literature review with descriptive analysis and identification with David Kelley \& Tim Brown's theory. The expert opinion of each explanation strengthens it. The results of this study were that with a good design thinking process PT Aplikasi Karya Anak Bangsa (Gojek) had produced a variety of solutions that were only online-based transportation applications. However, currently, Gojek also created a variety of services according to various community needs. It was also able to create business opportunities from a problem that occurred in the community.

Keywords: Design thinking; strategy; technology; gojek.

Abstrak. Penelitian ini bertujuan untuk menguraikan setiap tahapan design thinking pada PT Aplikasi Karya Anak Bangsa (Gojek) dalam upaya menciptakan solusi yang tepat dan efektif terhadap permasalahan yang timbul di masyarakat. Metodologi yang digunakan untuk penelitian ini yaitu melakukan tinjauan literatur dengan analisis deskriptif dan identifikasi dengan teori David Kelley \& Tim Brown dan diperkuat oleh pendapat ahli dari setiap penjelasannya. Hasil dari penelitian ini yaitu dengan proses design thinking yang baik PT Aplikasi Karya Anak Bangsa (Gojek) telah menghasilkan berbagai macam solusi yang tadinya hanya berupa aplikasi transportasi berbasis daring, namun saat ini Gojek juga menciptakan berbagai macam layanan sesuai dengan berbagai kebutuhkan masyarakat. Selain itu, juga mampu menciptakan peluang bisnis dari sebuah permasalahan yang terjadi di masyarakat.

Kata kunci : Design thinking; strategi; teknologi; gojek.

\section{Pendahuluan}

$\mathrm{P}$ ermasalahan mengenai kemacetan di kota-kota besar terutama di Jakarta menjadi permasalahan yang sering kali dikeluhkan oleh masyarakat. Permasalahan kemacetan ini sangat berdampak bagi kegiatan masyarakat terutama dalam hal mobilitas warga. Kemacetan telah banyak membuang waktu dan menghambat aktivitas masyarakat Jakarta. Apalagi Jakarta dengan segala aktivitas masyarakatnya yang terbilang tinggi. Produktifitas masyarakat menjadi menurun hanya karena kemacetan. Menurut Menteri Perencanaan Pembangunan Nasional (PPN)/Bapenas Bambang Brodjonegoro dalam sebuah artikel di website liputan6.com pada tahun 2019 mengatakan kerugian ekonomi akibat kema- 
cetan di Jakarta pada tahun 2013 sebesar 65 triliun rupiah, sedangkan pada tahun 2019 kerugian yang diakibatkan oleh kemacetan di Jakarta diperkirakan sebesar 100 triliun rupiah. Hal ini tentunya bukan berita baik bagi keberlangsungan hidup masyarakat Jakarta. Untuk itu, permasalahan mengenai kemacetan ini harus diselesaikan dengan menghadirkan solusi-solusi alternatif terutama ketersediaan transportasi yang mudah diakses dan memiliki mobilitas yang tinggi untuk mendukung aktivitas masyarakat Jakarta.

Bermula dari permasalahan tersebut lahirlah sebuah inovasi yang diciptakan oleh salah satu perusahaan aplikasi yaitu PT Aplikasi Karya Anak Bangsa (Gojek). Fenomena Gojek di Indonesia memberikan banyak perubahan pada kehidupan sehari-hari mayarakat. Kehadiran Gojek memberikan solusi dengan menghadirkan banyak layanan yang dibutuhkan masyarakat seperti layanan ojek online, pembelian makanan, pengiriman, jasa pijat, jasa membersihkan rumah, dan berbagai fasilitas layanan lainnya yang mampu membantu dan memenuhi kebutuhan masyarakat, terutama dalam permasalahan ketersediaan transportasi alternatif untuk mendukung aktivitas masyarakat.

Kehadiran Gojek juga mendapat respon positif dari masyarakat. Dari 9 tahun berdirinya sampai saat ini, Gojek telah banyak mengalami peningkatan. Dalam website resminya www.gojek.com saat ini Gojek mengklaim telah memiliki lebih dari satu juta mitra driver Gojek, lebih dari 125 juta orang telah mengunduh aplikasi
Gojek, dan terdapat sebanyak 100 juta transaksi yang ada pada aplikasi Gojek serta jangkauan Gojek lebih dari 50 kota yang tersebar di Indonesia. Valuasi perusahaannya pun saat ini telah lebih dari 39 Miliar dolar U.S yang menjadikan Gojek startup "Unicorn" pertama dari Indonesia.

Perkembangan yang cukup signifikan pada Gojek ini tidak lepas dari design thinking yang dibuat oleh Gojek. Hal ini karena Gojek mampu memberikan solusi efektif dan tepat bagi pemenuhan kebutuhan masyarakat sehingga mendapat respon baik dari masyarakat. Gojek memanfaatkan teknologi sebagai ujung tombak dengan tetap menjadikan manusia sebagai pusat interaksi dan kendali dalam menciptakan sebuah solusi.

Hal ini sejalan dengan pernyataan (Kolko, 2015) orang-orang membutuhkan agar interaksi mereka dengan teknologi dan sistem kompleks lebih sederhana, intuitif, dan menyenangkan. Ketika dilakukan dengan baik, desain yang berpusat pada manusia juga mampu meningkatkan pengalaman pengguna di setiap titik sentuhan yang ada pada produk dan mendorong penciptaan produk dan layanan yang sangat beresonansi dengan pelanggan. Desain juga bersifat empatik, dengan demikian secara implisit mendorong pendekatan manusia yang lebih mudah diterima dan mampu memiliki nilai bisnis.

Design thinking juga terbukti mampu memberikan dampak nyata dalam bisnis. Salah satu bukti nyata lainnya bisa dilihat dari peningkatan design value index perusahaanperusahaan besar di Amerika. 


\section{Gambar 1. Design Value Index 2016}

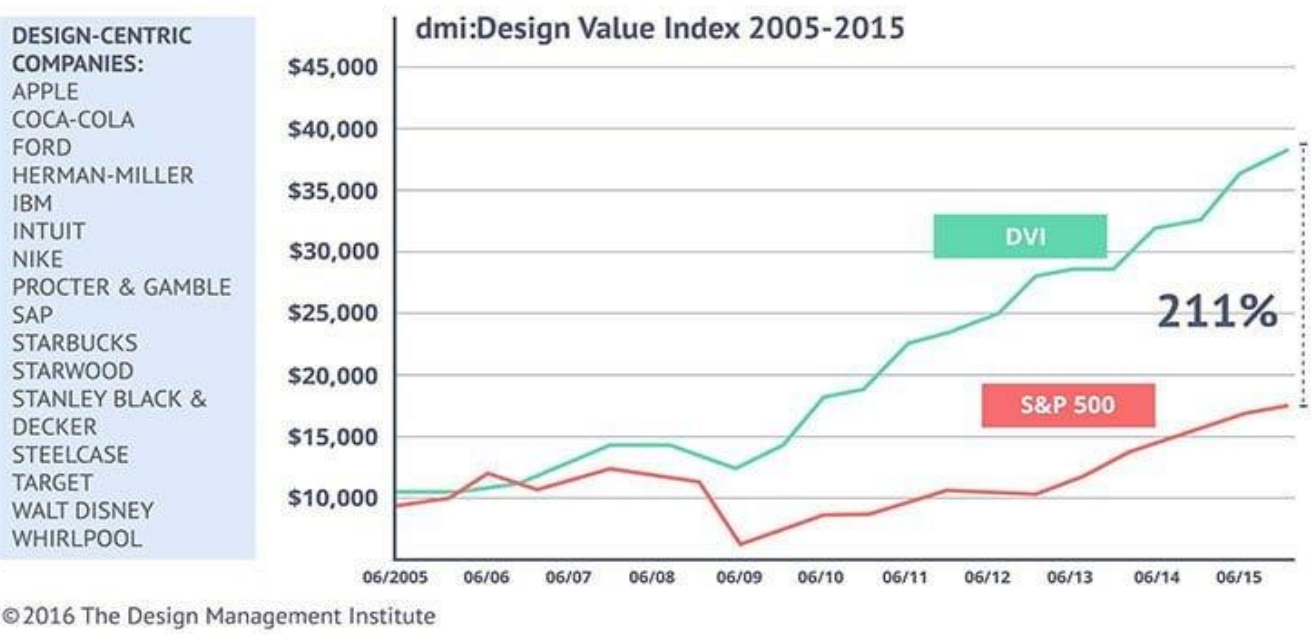

Sumber: The Design Management Institute (2016)

Diagram pada Gambar 1 mendeskripsikan mengenai perusahaan yang memiliki fokus pada penerapan design thinking seperti Apple, Pepsi, Procter \& Gamble, dan SAP telah mengungguli perusahaan seperti $\mathrm{S} \& \mathrm{P}$ 500 dengan kenaikan design value index $211 \%$. Hal ini membuktikan jika design thinking dilaksanakan dengan benar dan strategis dapat mempengaruhi hasil bisnis dan menghasilkan keunggulan kompetitif yang nyata. Selain itu, ketika prinsipprinsip desain diterapkan pada strategi dan inovasi tingkat keberhasilan untuk inovasi meningkat secara dramatis (Design Management Institute and Motiv Strategies, 2015).

Desain juga mengubah cara perusahaan dalam menciptakan nilai. Fokus inovasi saat ini telah bergeser dari yang awalnya berfokus pada hal teknis menjadi berfokus pada desain, dari sebelumnya product centric ke customer centric, dan dari fokus pada pemasaran kini beralih ke fokus pada pengalaman pengguna. Untuk itu, design thinking merupakan inti dari pengembangan strategi yang efektif dan perubahan organisasi (Naiman, 2019).

Oleh karena itu, peneliti tertarik untuk membahas design thinking yang Gojek lakukan dalam merancang solusi yang tepat pada masalah yang terjadi di masyarakat, dan menjadikan hal tersebut sebagai strateginya dalam meningkatkan daya saing perusahaan. Selain itu, mereka juga mampu menciptakan peluang bisnis dari permasalahan transportasi yang terjadi di masyarakat. Penelitian ini diharapkan memberikan ulasan yang bermanfaat dalam upaya menciptakan bisnis yang baik dan berkelanjutan.

\section{Kajian Literatur}

\section{Design Thinking}

Menurut (Kelley \& Brown, 2018) design thinking adalah pendekatan yang berpusat pada manusia terhadap inovasi yang diambil dari perangkat perancang untuk mengintegrasikan kebutuhan orangorang, kemungkinan teknologi, dan persyaratan untuk kesuksesan bisnis. 


\section{Gambar 2. Elemen dalam Design Thinking}

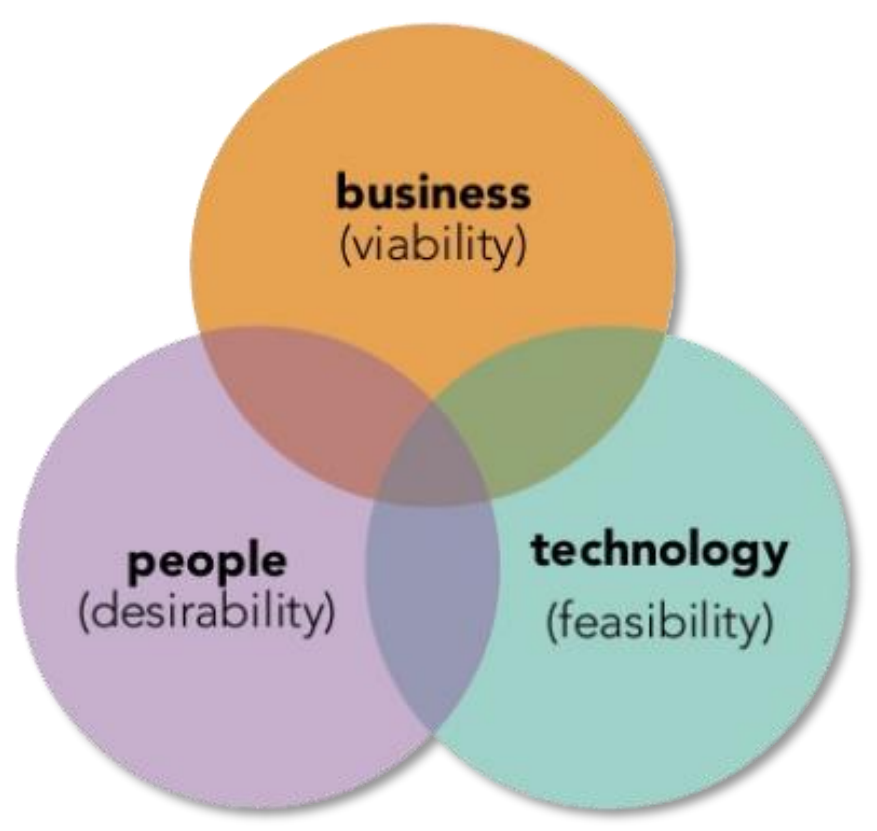

Pada Gambar 2 dapat diketahui elemen dalam membuat desain sebuah solusi, metode ini menggabungkan beberapa elemen sebagai bahan pertimbangan dalam menciptakan ide yang dibutuhkan. Design thinking mempertimbangkan kebutuhan pengguna dan menggabungkannya dengan kemampuan teknologi yang sesuai, sehingga mampu menjadi produk bisnis yang baik karena memberikan kelayakan dan solusi efektif bagi suatu permasalahan. Selain itu, design thinking bukan hanya tentang menciptakan sebuah produk tetapi (Kelley \& Brown, 2018) menekankan bahwa desain layaknya sebuah tim dengan tiga nilai utama:

1. Many eyes - Dalam desain yang akan dibuat kita bisa mengolaborasikan berbagai macam keahlian untuk mencapai hasil yang diinginkan. Tidak bergantung pada satu keahlian tapi melainkan berbagai macam keahlian seperti teknik, pengelolaan sumber daya manusia, komunikasi, etnografi, dan sebagainya. Perbedaan pandangan dari setiap anggota tim bisa menjadi sebuah keunikan yang mampu memberikan sudut pandang yang luas yang tidak dapat dilihat oleh yang lainnya.
2. Customer View Point - Tim desain harus mampu merespon dan memahami cara pandang customer terhadap suatu hal atau sebuah permasalahan yang terjadi dan memahami reaksi dan harapan mereka terhadap hal itu.

3. Tangibility - Dari identifikasi yang didapat, tim desain membuat prototype atau maket untuk melakukan berbagai percobaan dan mempelajari reaksi yang terjadi.

Design thinking mampu memberikan solusi bagi beberapa permasalahan yang kompleks. Tim desain menghasilkan suasana kolaborasi yang sering kali mengarah pada terciptanya terobosan untuk menyelesaikan masalah yang ada. Ketika tim desain menyatukan semua pemangku kepentingan berbagai perusahaan, mereka sering dapat memenangkan komitmen dari berbagai divisi perusahaan untuk melihat ide-ide baru hingga menjadi sebuah solusi. Perlu dicatat bahwa design thinking bukan satusatunya metode yang berhasil untuk menghasilkan kolaborasi dan mampu menyelesaikan semua permasalahan (Macfadyen, 2014). 
Namun, seiringnya perkembangan zaman, esensi dari proses desain semakin berubah dan berevolusi. Desain bukan hanya sekedar membuat sebuah produk atau aplikasi yang akan laku di pasaran, memiliki bentuk yang indah dan menarik, ataupun mudah untuk dibuat. Desain sekarang ini adalah berkaitan dengan penciptaan sesuatu atau ide yang sesuai keinginan dan kebutuhan pengguna atau banyak orang.

Menurut (Kelley \& Brown, 2018) design thinking memiliki beberapa elemen penting yaitu :

1. People Centered : dalam tahapan ini yang perlu diperhatikan bahwa setiap tindakan berpusat pada kebutuhan dan kepentingan pengguna.

2. Highly Creative : metode ini juga memberikan keleluasaan dan kreativitas yang tinggi, sehingga dalam proses perencanaannya tidak baku dan kaku.

3. Hands $O n$ : proses desain juga perlu dilakukan percobaan yang nyata tidak hanya sebuah ide atau gagasan berupa gambar dan teori yang tertuang dalam sebuah perencanaan semata.

4. Iterative : proses desain merupakan sebuah proses dengan tahapantahapan yang dilakukan berulangulang untuk melakukan improvisasi dan menghasilkan sebuah produk atau aplikasi yang baik yang sesuai dengan harapan customer.

Proses yang dilakukan dengan metode design thinking akan menghasilkan produk yang tidak hanya dapat dijual atau menciptakan sebuah produk yang unggul karena menggunakan teknologi yang paling canggih. Metode ini juga menggabungkan kebutuhan user atau pengguna, dengan kemampuan teknologi yang sesuai dan mampu menyelesaikan sebuah permasalahan saja, namun tetap mampu menjadi sesuatu yang dapat berhasil dalam sebuah bisnis.

Dalam membuat sebuah produk atau aplikasi dengan metode design thinking, (Kelley \& Brown, 2018) menjelaskan terdapat beberapa tahapan yang dibutuhkan untuk menghasilkan produk yang sesuai.

\section{Gambar 3. Tahapan Design Thinking}

\section{Design Thinking Process ; at d.school of Stanford University}

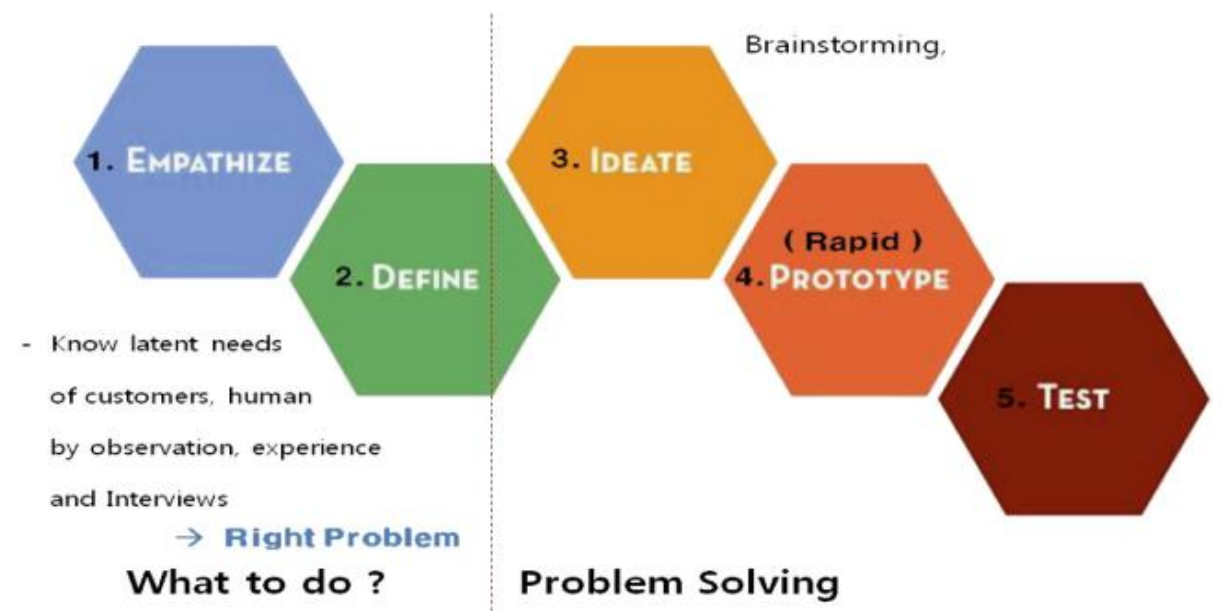

Sumber: Design Thinking Process Stanford University (2019) 


\section{Empathize}

Ketika sudah mengetahui user atau pengguna yang akan dituju, maka seorang design thinker perlu mengetahui pengalaman, emosi, dan situasi dari si pengguna. Mencoba menempatkan diri sebagai pengguna sehingga dapat benar-benar memahami kebutuhan pengguna. Hal ini dapat dilakukan dengan melakukan wawancara, observasi kehidupan pengguna, dan cara lainnya.

2. Define

Setelah design thinker mengerti kebutuhan pengguna, maka desainer perlu menggambarkan sebuah ide atau pandangan user yang akan menjadi dasar dari produk atau aplikasi yang akan dibuat. Hal ini dapat dilakukan dengan membuat list kebutuhan user dan menggunakan pengetahuan mengenai kondisi yang sedang terjadi.

3. Ideate

Dengan kebutuhan yang ada, maka desainer perlu menggambarkan solusi yang dibutuhkan. Hal ini dapat dilakukan melakukan evaluasi bersama tim desain dengan menggabungkan kreativitas dari masing-masing desainer.

4. Prototype

Ide yang sudah ada sebelumnya maka perlu langsung diimplementasikan dalam sebuah aplikasi atau produk uji coba. Perlu dihasilkan sebuah produk nyata dan kemungkinan skenario penggunaan.

5. Test

Dari produk atau aplikasi uji coba yang sudah dibuat, maka akan dilakukan sebuah percobaan dengan pengguna. Dari pengalaman pengguna dalam menggunakan produk uji coba, maka akan didapatkan masukkan untuk membuat produk yang lebih baik dan melakukan perbaikan pada produk yang ada.

\section{Metode Penelitian}

Metodologi yang digunakan untuk penelitian ini yaitu melakukan tinjauan literatur dengan mencari referensi teori yang relevan dengan kasus atau permasalahan yang ditemukan. Studi literatur adalah cara penelitian yang digunakan dengan mengumpulkan berbagai macam informasi, teori dan referensi yang sesuai dengan penelitian yang dilakukan untuk membahas dan memberikan ulasan pada sebuah permasalahan. Selain itu, penelitian ini menggunakan analisis deskriptif dan identifikasi menggunakan teori design thinking. David Kelley membagi beberapa tahapan yaitu 1) Empathize, 2) Define, 3) Ideate, 4) Prototype, 5) Test, yang bertujuan untuk memberikan kajian atau ulasan mengenai design thinking PT Aplikasi Karya Anak Bangsa.

\section{Hasil dan Pembahasan}

Menurut Russell L. Ackoff et al. (2006) design thinking yang ideal adalah cara berpikir tentang perubahan yang tampak sederhana hingga mampu dinyatakan dalam menyelesaikan masalah dalam bentuk apapun, cara untuk mendapatkan hasil terbaik adalah membayangkan seperti apa solusi yang ideal kemudian melakukan pengamatan dan menghasilkannya sampai menjadi solusi yang nyata.

Sedikit berbeda dengan pendapat sebelumnya. Menurut (Collopy, 2009), design thinking lebih besar dari hanya sebuah aplikasi untuk menyelesaikan masalah dalam manajemen, organisasi, dan kehidupan sosial design thinking dianggap sebagai metode yang terdiri dari banyak teknik tertentu yang sudah tersirat dalam sistem berpikir.

Dalam konteks design thinking Gojek, mereka memahami bahwa banyak hal yang akan terlibat dalam penciptaan solusi kemacetan yang sedang melanda. Aspek-aspek sosial, ekonomi, hukum, dan aspek-aspek lainnya merupakan hal yang 
patut diperhatikan dalam upaya menciptakan solusi yang tepat dan efektif.

Salah satu bukti beberapa aspek yang memiliki dampak baik dari hasil design thinking Gojek yang berdampak pada masyarakat adalah aspek ekonomi,
Berdasarkan data hasil pengamatan Gambar 4, dampak Gojek pada aspek ekonomi dan sosial yaitu:

1. Perekonomian Nasional \& Masyarakat:

Gambar 4. Kontribusi Gojek pada Perekonomian Nasional dan Masyarakat.

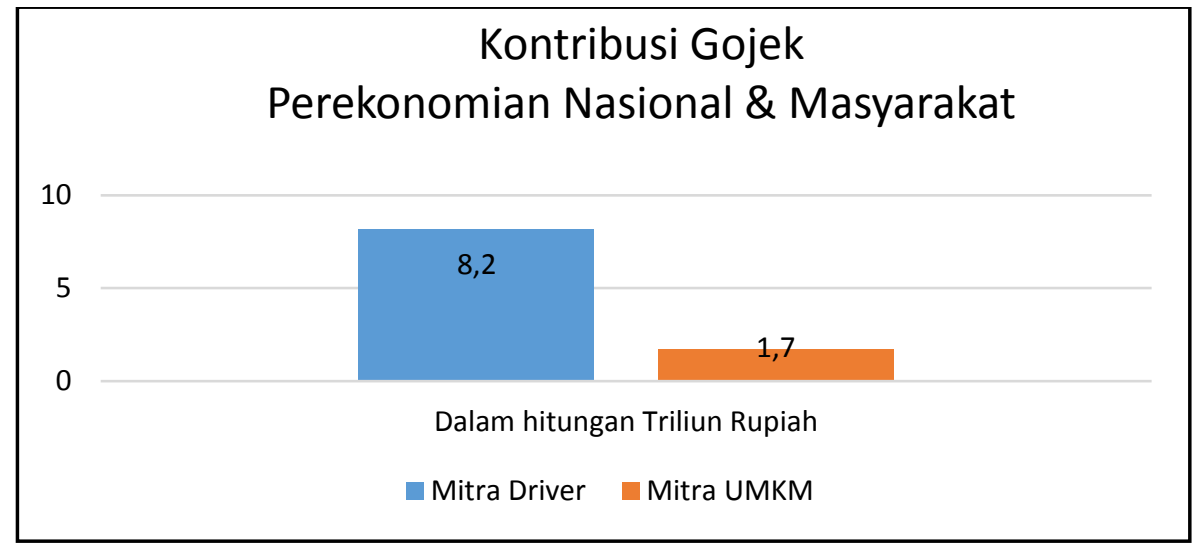

Sumber: Lembaga Demografi Universitas Indonesia (2018)

2. Mitra Pengemudi:

- Mengurangi pengangguran dengan menciptakan kesempatan kerja.

- Meningkatkan pendapatan mitra pengemudi dan membantu menyejahterakan keluarga mitra pengemudi.

- Meningkatkan kualitas hidup mitra pengemudi.

3. Mitra UMKM:

- Mendukung UMKM menjadi berbasis online.

- Meningkatkan volume transaksi mitra UMKM.

- Membuka akses pasar lebih luas, mendorong penggunaan teknologi, dan meningkatkan aset usaha.

Pada penjelasan di atas bisa diartikan jika Gojek merumuskan design thinking tidak sembarangan hingga terbukti mampu memberikan dampak positif yang begitu besar di masyarakat. Menurut (Kelley \& Brown, 2018) ada 5 tahapan pada design thinking:

\section{Emphatize}

Dalam membaca situasi dan kondisi dari pemasalahan mengenai kemacetan dan penciptaan solusi transportasi, Gojek mengawalinya dengan menanamkan empati dari setiap keresahaan masyarakat mengenai kemacetan dan solusi alternatif untuk menciptakan transportasi yang sesuai dengan harapan masyarakat. Upaya Gojek memahami sudut pandang pengguna tergambar dalam pernyataan Chief Executive Officer (CEO) Gojek Nadiem Makarim dalam interview pada laman liputan6.com (8 Juli 2018):

"Dulu saya naik ojek ke mana-mana. Karena kalau naik mobil gak akan nyampe. Saya rasa banyak orangorang yang dulu tidak percaya bahwa ojek bisa profesional. Hal ini cukup membuat saya frustrasi, karena saya juga harus mengetahui secara persis pengendara ojek di Indonesia. Dengan mengetahui mereka secara personal, saya segera sadar bahwa sektor ini benar-benar sungguh bernilai." 
Hal ini sejalan dengan pendapat (Goonetilleke \& Karwowski, 2016) tahap empati dari proses design thinking adalah sejauh mana kita mampu memahami dan merasakan permasalahan yang ada. Hal ini bisa dilakukan dengan menghasilkan caracara baru untuk mengatasi masalah lama, memahami dan mengubah respon orang lain sehingga kita dapat merasakan kepekaan yang ada di lingkungan tempat tinggal mereka.

\section{Define}

Dari empati tersebut kemudian Gojek berupaya menggabungkan semua saran dan keresahan yang dialami masyarakat dan menentukan beberapa poin penting. Dalam memaknai setiap keresahan, Gojek mencoba memahami setiap keresahan dan mengisinya dengan sebuah solusi. Menurut CEO Gojek Nadiem Makariem dalam sebuah wawancara pada laman liputan6.com menyampaikan:

"Konsumen adalah mereka yang memiliki masalah hari demi hari, dan kami menciptakan produk dimana Go-Jek dapat menembus ruang kosong tersebut."
Dari pernyataan di atas Gojek mencoba menegaskan jika mereka mampu memahami setiap keresahan yang dirasakan masyarakat, kemudian menjabarkannya dengan solusi yang dianggap sulit untuk didapat namun faktanya berhasil memberikan dampak positif. Sejalan dengan itu, menurut (Tim Brown \& Jocelyn Wyatt, 2016) fase define adalah sebuah proses mensintesiskan temuan dari empati yang didapatkan dari pengguna untuk membentuk sudut pandang pengguna yang akan dituangkan pada penciptaan solusi yang akan dibuat.

\section{Ideate}

Posisi Gojek dalam ekosistem bisnis yang mereka ciptakan, Gojek berusaha berperan sebagai penghubung antara konsumen dan mitra yang bekerjasama dengan mereka dari setiap layanan yang mereka ciptakan. Hal ini menunjukkan jika Gojek mendesain strateginya dengan begitu komprehensif dengan memaksimalkan setiap peluang yang ada. Pada praktiknya Gojek berupaya menciptakan beragam solusi berupa layanan-layanan yang mampu membantu memenuhi kebutuhan masyarakat.

Gambar 5. Layanan pada Aplikasi Gojek

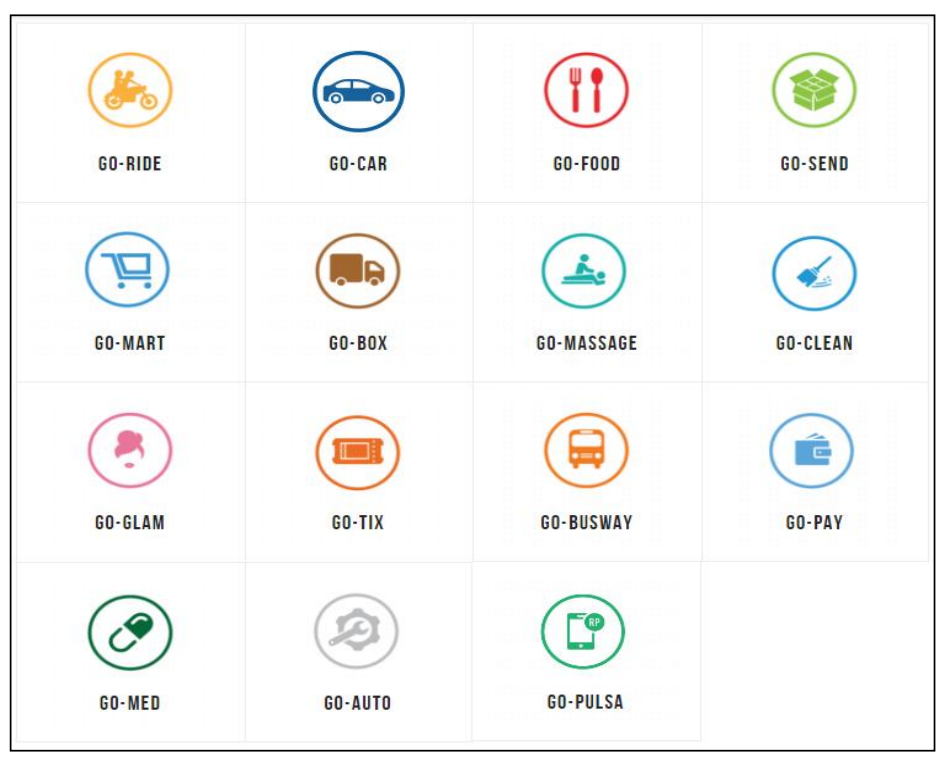

Sumber: Karinov.co.id (2018) 
Menurut (Lee, 2018) fase ini adalah fase untuk menjelajahi berbagai solusi yang mungkin dihasilkan dalam jumlah yang besar dan beragam, memungkinkan kita untuk melangkah lebih jauh dan mengeksplorasi berbagai ide.

Dalam banyak kasus, metode untuk menghasilkan ide hampir tergantung pada sedikit atau banyaknya diskusi dan media untuk memberikan pendapat dari berbagai tim yang multidisiplin.

\section{Prototype}

Menurut (Lee, 2018) fase ini adalah fase untuk mengubah ide-ide menjadi bentuk fisik yang cepat dan murah sehingga kita dapat menjalani dan berinteraksi dengan ide tersebut, dan dalam prosesnya, fase ini mempelajari dan mengembangkan ide dengan lebih banyak empati.

Pada awal berdirinya tahun 2010, Gojek membuat aplikasi yang awalnya hanya sebagai pusat call center bagi penyedia ojek konvensional yang berjumlah 20 orang pengemudi. (sumber : www.gojek.com). Kemudian Gojek melakukan pembaruan dan evaluasi untuk mengembangkan aplikasi yang telah mereka buat. Hal ini mereka lakukan melihat respon positif dari masyarakat mengenai keberadaan aplikasi yang mereka buat.

\section{Gambar 6. Diagram Context Aplikasi Gojek}

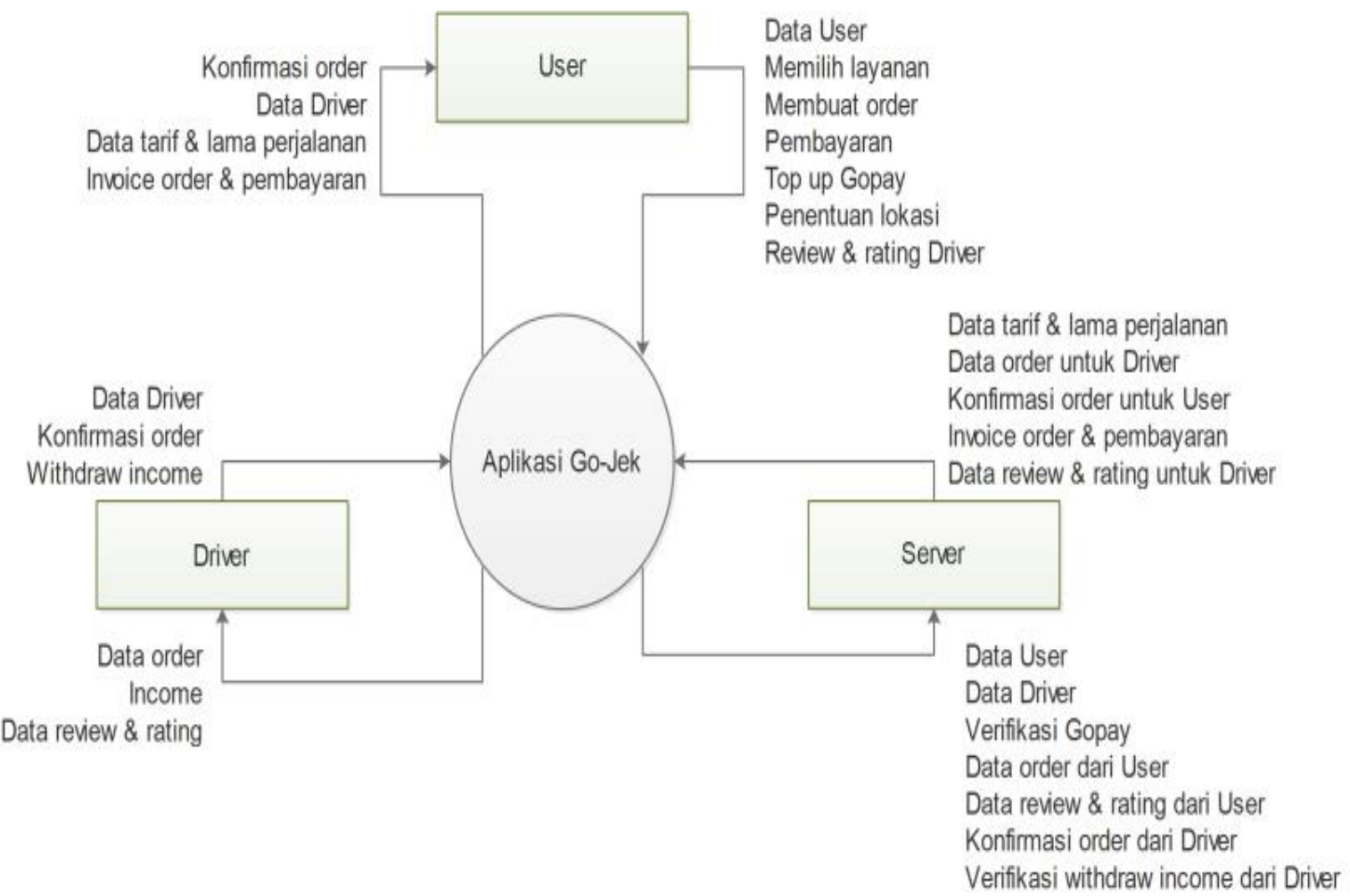

Sumber: Karinov.co.id (2018) 
Sejalan dengan itu (Tim Brown \& Wyatt, 2016) mengatakan fase prototype yaitu mengubah ide menjadi produk dan layanan aktual yang kemudian diuji, diulang, dan diperbaiki. Melalui pembuatan prototype, proses design thinking berupaya untuk mengungkap tantangan implementasi yang tidak terduga dan konsekuensi yang tidak diinginkan untuk mencapai kesuksesan jangka panjang yang lebih andal.

\section{Test}

Pada tahun 2015, Gojek meluncurkan Aplikasi Go-Ride. Melihat respon positif, Gojek mulai mencoba melakukan test untuk mendapatkan respon dari masyarakat. Pada tahun 2015 Gojek mendapatkan peningkatan mitra driver dari 20 orang menjadi 800 orang mitra driver (sumber: Techinasia.com).

Menurut (Lee, 2018) dalam fase ini cobalah membuat produk dengan resolusi tinggi dan gunakan pengamatan dan umpan balik untuk memperbaiki prototype, mempelajari lebih lanjut tentang pengguna, dan memperbaiki sudut pandang asli kita dalam memahami segala kondisi.

Melihat respon yang baik dan peningkatan yang dialami Gojek, sampai saat ini mitra yang bergabung dengan Gojek lebih dari 1 juta mitra driver (sumber: www.gojek.com). Belum lagi mitra dari layanan lain yang ada pada Gojek saat ini. Hal ini menunjukkan bahwa Gojek mampu melakukan evaluasi dan pengembangan dari setiap hal yang diterapkan sebelumnya.

\section{Kesimpulan}

Dari fenomena kemacetan yang terjadi, PT Aplikasi Karya Anak Bangsa (Gojek) telah menghasilkan berbagai macam solusi yang tadinya hanya berupa aplikasi transportasi berbasis online, namun saat ini Gojek juga menciptakan berbagai macam layanan yang dibutuhkan masyarakat dari sebuah proses design thinking yang baik.
Solusi ini dihasilkan dari kemampuan Gojek dalam membaca kondisi, dan memetakan segala aspek yang berkaitan dengan permasalahan yang terjadi di masyarakat. Menguraikan setiap permasalahan yang kemudian dirumuskan pada setiap tahapan design thinking. Memperlihatkan kemampuan Gojek dalam menangkap, merespon, kemudian mengidentifikasi setiap sisi permasalahan dan peluang. Sehingga mampu menghasilkan solusi yang tepat dan efektif dalam menyelesaikan permasalahan yang hadir di masyarakat. Terutama dalam hal membantu mobilitas dan aktivitas masyarakat sehari-hari.

\section{Daftar Pustaka}

Ackoff, R. L., Magidson, J., \& Addison, H. J. (2006). Introduction to Idealized Design: Creating an Organization's Future. Upper Saddle River: Wharton School Publishing.

Brown, T., \& Wyatt, J. (2010). Design Thinking for Social Innovation. Stanford Social Innovation Review, 8, 30-35. doi: https://doi.org/10.1596/1020797X_12_1_29

Cerita Nadiem Makarim Bangun Go-Jek Dari Nol Hingga Raih Sukses. (7 Oktober 2019). liputan6.com. Diakses dari https://www.liputan6.com/bisnis/rea d/3582132/cerita-nadiem-makarimbangun-go-jek-dari-nol-hingga$\underline{\text { raih-sukses }}$

Collopy, F. (2019). Why the failure of systems thinking should inform the future of Design Thinking (06.07.09). Design Issues, 35(2), 97-100. doi: https://doi.org/10.1162/desi_a_0053 $\underline{8}$

Design Thinking Process. (2019). $d$ school.stanford.edu. Diakses dari https://dschool.stanford.edu/executi 
ve-education/dbootcamp

Gojek Profile. (7 Oktober 2019). Gojek. Diakses dari https://www.gojek.com/about/

Goonetilleke, R., \& Karwowski, W. (2016). Advances in Physical Ergonomics and Human Factors: Proceedings of the AHFE 2016 International Conference on Physical Ergonomics and Human Factors, July 27-31, 2016, Walt Disney World®, Florida, USA (Vol. 489). doi: https://doi.org/10.1007/978-3-31941694-6

Karinov, K. (26 Oktober 2018). Contoh Analisis Swot dan Bisnis Model dari Perusahaan Gojek. Karinov.com Diakses dari https://karinov.co.id/analisis-swotbisnis-model-Gojek/

Kelley, D., \& Brown, T. (2018). An introduction to Design Thinking. Institute of Design at Stanford. doi: https://doi.org/10.1027/21512604/a000142

Kolko, J., (September 2015). The Evolution of Design Thinking. Harvard Business Review. Diakses dari https://hbr.org/2015/09/designthinking-comes-of-age

Lee, K. (2018). Innovative Design Thinking Process with TRIZ. In: Cavallucci D., De Guio R., Koziołek S. (eds) Automated Invention for Smart Industries. TFC 2018. IFIP Advances in Information and Communication Technology, vol 541. Springer, Cham. doi: https://doi.org/10.1007/978-3-03002456-7_20

Macfadyen, J. S. (2014). Design Thinking. Holistic Nursing Practice, 28(1), 35. doi: https://doi.org/10.1097/HNP.00000 $\underline{00000000008}$

Niman, L. (20 Mei 2019). Design
Thinking as a Strategy for Innovation. The European Business Review. Diakses dari https://www.europeanbusinessrevie w.com/design-thinking-as-astrategy-for-innovation/

Pratama, A. H. (13 Agustus 2016). How Gojek Became Unicorn. Techinasia. Diakses dari https://www.techinasia.com/howgo-jek-became-unicorn

Sofian, A. (2 Juli 2019). Kerugian Ekonomi Akibat Kemacetan Ibu Kota Jakarta. Liputan6. Diakses dari https://www.liputan6.com/news/rea d/4003307/foto-kerugian-ekonomiakibat-kemacetan-ibu-kotajakarta?page $=1$

The Design Management Institute DMI Value Index 2015. (2019). dmi.org. Diakses dari https://www.dmi.org/page/2015DVI andOTW

Walandouw, P., Primaldhi, A., Wisana, I D. G. K., \& Nugroho, A. H. (2018). Dampak GO-JEK terhadap Perekonomian Indonesia 2017. Lembaga Demografi Universitas Indonesia. Diakses dari http://ldfebui.org/special-project/

Yadika, B. (8 Juli 2018). Cerita Nadiem Makarim Bangun Go-Jek Dari Nol Hingga Raih Sukses. Liputan6.com. Diakses dari https://www.liputan6.com/bisnis/rea d/3582132/cerita-nadiem-makarimbangun-go-jek-dari-nol-hinggaraih-sukses 